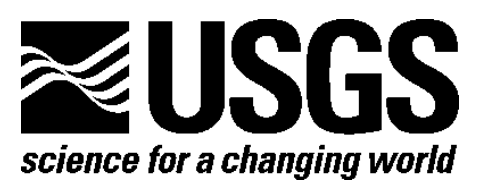

\title{
Evaluation of Extraction Methods for Hexavalent Chromium Determination in Dusts, Ashes, and Soils
}

By Ruth E. Wolf and Stephen A. Wilson

Open-File Report 2010-1243

U.S. Department of the Interior

U.S. Geological Survey 


\section{U.S. Department of the Interior \\ KEN SALAZAR, Secretary}

\section{U.S. Geological Survey \\ Marcia K. McNutt, Director}

U.S. Geological Survey, Reston, Virginia 2010

For product and ordering information:

World Wide Web: http://www.usgs.gov/pubprod

Telephone: 1-888-ASK-USGS

For more information on the USGS-the Federal source for science about the Earth,

its natural and living resources, natural hazards, and the environment:

World Wide Web: http://www.usgs.gov

Telephone: 1-888-ASK-USGS

Suggested citation:

Wolf, Ruth E., and Wilson, Stephen A., 2010, Evaluation of extraction methods for hexavalent chromium determination in dusts, ashes, and soils: U.S. Geological Survey Open-File Report 2010-1243, 22 p.

Any use of trade, product, or firm names is for descriptive purposes only and does not imply endorsement by the U.S. Government.

Although this report is in the public domain, permission must be secured from the individual copyright owners to reproduce any copyrighted material contained within this report. 


\title{
Evaluation of Extraction Methods for Hexavalent Chromium Determination in Dusts, Ashes, and Soils
}

\author{
By Ruth E. Wolf and Stephen A. Wilson
}

\begin{abstract}
One of the difficulties in performing speciation analyses on solid samples is finding a suitable extraction method. Traditional methods for extraction of hexavalent chromium, Cr(VI), in soils, such as SW846 Method 3060A, can be tedious and are not always compatible with some determination methods. For example, the phosphate and high levels of carbonate and magnesium present in the U.S. Environmental Protection Agency (USEPA) Method 3060A digestion for Cr(VI) were found to be incompatible with the High Performance Liquid Chromatography-Inductively Coupled Plasma-Mass Spectrometry (HPLC-ICP-MS) detection method used by our laboratory. Modification of Method 3060A by eliminating the use of the phosphate buffer provided improved performance with the detection method, however dilutions are still necessary to achieve good chromatographic separation and detection of $\mathrm{Cr}(\mathrm{VI})$.

An ultrasonic extraction method using a $1 \mathrm{mM} \mathrm{Na}_{2} \mathrm{CO}_{3}-9 \mathrm{mM} \mathrm{NaHCO}$ buffer solution, adapted from Occupational Safety and Health Administration (OSHA) Method ID215, has been used with good results for the determination of $\mathrm{Cr}(\mathrm{VI})$ in air filters. The average recovery obtained for BCR545 - Welding Dust Loaded on Filter (IRMM, Belgium) using this method was 99 percent (1.2 percent relative standard deviation) with no conversion of $\mathrm{Cr}(\mathrm{VI})$ to $\mathrm{Cr}(\mathrm{III})$ during the extraction process.

This ultrasonic method has the potential for use with other sample matrices, such as ashes and soils. Preliminary investigations using NIST 2701 (Hexavalent Chromium in Contaminated Soil) loaded onto quartz filters showed promising results with approximately 90 percent recovery of the certified $\mathrm{Cr}(\mathrm{VI})$ value. Additional testing has been done using NIST 2701 and NIST 2700 using different presentation methods. Extraction efficiency of bulk presentation, where small portions of the sample are added to the bottom of the extraction vessel, will be compared with supported presentation, where small portions of the sample are loaded onto a quartz filter prior to extraction. In addition, results obtained from the standard grinding preparation of NIST 2701 and NIST 2700 will be compared with micronizing to reduce particle size before extraction.
\end{abstract}

\section{Introduction}

This report contains slides and speaker's notes used for an oral presentation given at the 2010 National Environmental Monitoring Conference (http://www.nemc.us/) held in Washington, D.C., in August 2010.

The slides also contain preliminary results for the determination of hexavalent chromium, Cr(VI), in two standard reference materials (SRM 2701 and SRM 2700) prepared by the U.S. Geological Survey in a collaboration with the National Institute for Standards and Technology (NIST) and the New Jersey Department of Environmental Protection. Speciation analysis of these samples for 
hexavalent chromium, $\mathrm{Cr}(\mathrm{VI})$, was carried out by High Performance Liquid Chromatography (HPLC) coupled to Inductively Coupled Plasma Mass Spectrometry (ICP-MS) using a method discussed by Wolf and others (2007). Issues encountered during speciation analysis including calibration standard purity and stability, sample stability, and vial contamination are also addressed. The use of an analytical spike on every sample is discussed as a means of assessing overall data quality and determining sample matrix effects on species stability and possible species interconversions.

The slides provide an overview and discussion of the various methods available for extraction of $\mathrm{Cr}(\mathrm{VI})$ from solid materials. The most commonly used method, U.S. Environmental Protection Agency (USEPA) Method 3060A has some disadvantages and is not fully compatible with the detection method used in this study. Other extraction methods using phosphate and ammonium sulfate buffers were also incompatible with the analytical determination method. Based on work done on air filter samples, a new extraction method based on methods used by the Occupational Safety and Health Administration (OSHA) and the National Institute for Occupational Safety and Health (NIOSH) using a $1 \mathrm{mM}$ $\mathrm{Na}_{2} \mathrm{CO}_{3} / 9 \mathrm{mM} \mathrm{NaHCO}$ buffer (10mM sodium bicarbonate buffer) at a $\mathrm{pH}$ of 9-9.3 was tested for use with the NIST SRMs 2701 and 2700. Preliminary studies using a 3-hour ultrasonic extraction with the 10-mM sodium bicarbonate buffer resulted in 99 percent recoveries for $\mathrm{Cr}(\mathrm{VI})$ from BCR 545 (IRMM, Belgium), a reference material for $\mathrm{Cr}(\mathrm{VI})$ in welding dust on an air filter, and acceptable, 88 percent recovery for NIST 2701 suspended on quartz filter media.

Results in Slide 16 for subsequent studies using USEPA Method 3060A as written showed that recoveries for $\mathrm{Cr}(\mathrm{VI})$ were low (75 percent) for NIST 2701. It is postulated that some of the losses might be occurring from coprecipitation of the $\mathrm{Cr}(\mathrm{VI})$ with the $\mathrm{Mg}\left(\mathrm{CO}_{3}\right)_{2} / \mathrm{Mg}(\mathrm{OH})_{2}$ precipitate that is formed when $\mathrm{Mg}^{2+}$ is added to eliminate concomitant elements that may reduce $\mathrm{Cr}(\mathrm{VI})$ or that the sample matrix is responsible for oxidation/reduction reactions that reduce the amount of $\mathrm{Cr}(\mathrm{VI})$ present. Experiments performed using a modified version of USEPA Method 3060A resulted in increased recoveries of $\mathrm{Cr}(\mathrm{VI})$ of up to 85 percent for NIST 2701 when the $\mathrm{Mg}^{2+}$ coprecipitation reagent required by USEPA Method 3060A is omitted along with the phosphate buffer. The authors believe this increased recovery when $\mathrm{Mg}^{2+}$ is omitted is some indication that a portion of the $\operatorname{Cr}(\mathrm{VI})$ is being coprecipitated with the $\mathrm{Mg}\left(\mathrm{CO}_{3}\right)_{2} / \mathrm{Mg}(\mathrm{OH})_{2}$ precipitate. Further studies will be performed to confirm this, including Scanning Electron Microscopy (SEM) analysis of the USEPA Method 3060A precipitate. An additional experiment using a micronized portion (particle size reduced from approximately $200 \mu \mathrm{m}$ to approximately $30 \mu \mathrm{m}$ ) of NIST 2701 and the modified USEPA Method 3060A extraction resulted in 92 percent recovery of the $\mathrm{Cr}(\mathrm{VI})$ level stated on the certificate. Experiments with the 10 -mM sodium bicarbonate buffer resulted in 82 percent recoveries for NIST 2701 when $0.5 \mathrm{~g}$ of sample was extracted with $50 \mathrm{~mL}$ of extraction fluid on a hot plate at $90-95^{\circ} \mathrm{C}$ for one hour. Bulk ultrasonic extractions, where the sample was added to bottom of centrifuge tube and shaken periodically during extraction, performed with the $10 \mathrm{mM}$ sodium bicarbonate solution resulted in low (54 percent) recoveries for NIST 2701 as shipped where the particle size was approximately $200 \mu \mathrm{m}$. Micronizing the NIST 2701 sample to reduce the particle size to approximately $30 \mu \mathrm{m}$ prior to extraction improved recoveries to 63 percent. Recoveries were improved by using a quartz filter to support $0.05-0.15 \mathrm{~g}$ of the sample during the ultrasonic extraction to 61 percent and 72 percent for the as-shipped and micronized portions of NIST 2701, respectively.

Results for initial studies in Slide 17 using NIST 2700, which is a 1:40 dilution of the NIST 2701 material using ground high-purity quartz as a diluent, and the USEPA Method 3060A extraction as written gave an average $\mathrm{Cr}(\mathrm{VI})$ value of $13.8 \mathrm{mg} / \mathrm{kg}$ which was 100 percent recovery of predicted value of $13.8 \mathrm{mg} / \mathrm{kg}$ (based on the 1:40 dilution performed on NIST 2701 containing $551 \mathrm{mg} / \mathrm{kg} \mathrm{Cr}(\mathrm{VI})$ ). The results for the modified version of USEPA Method 3060A were higher than expected and it is believed 
that the samples may have been improperly labeled and confused with a different dilution (1:20) of NIST 2701. Another round of extractions will be performed to verify these results. The results for the hot plate and ultrasonic extractions were similar and resulted in somewhat low recoveries (65-72 percent) for all trials except for the micronized sample that was loaded on to a quartz filter where 101 percent recovery was obtained for $\mathrm{Cr}(\mathrm{VI})$.

These studies indicate that USEPA Method 3060A performed as written can lead to low recoveries for $\mathrm{Cr}(\mathrm{VI})$ in the NIST 2701 reference material. The modified version of USEPA Method 3060A where the magnesium coprecipitation reagent and the phosphate buffer were omitted resulted in higher (85 percent) recoveries of $\mathrm{Cr}(\mathrm{VI})$ in NIST 2701. The testing of an alternative extraction method using a $1 \mathrm{mM} \mathrm{Na}_{2} \mathrm{CO}_{3} / 9 \mathrm{mM} \mathrm{NaHCO}$ buffer solution at a $\mathrm{pH}$ of 9-9.3 on a hotplate for one hour gave results similar to the modified USEPA Method 3060A extraction of 82 percent for NIST 2701. The ultrasonic bulk method and filter supported methods gave low recoveries for Cr(VI) in NIST 2701; however, the filter supported extraction resulted in higher recoveries as expected. Preliminary results for NIST 2700 were close to the predicted value using USEPA Method 3060A; however, the experiments need to be repeated to confirm the results and sample identity using the modified version of USEPA Method 3060A. As anticipated, experiments with reduced particle sizes resulted in increased recoveries for both NIST 2701 and 2700. Further testing is needed at additional extraction times and temperatures for the ultrasonic extraction method using both NIST 2701 and NIST 2700. Additional experiments are planned to evaluate potential species interconversion issues with the modified USEPA 3060A and the 10-mM sodium bicarbonate hot plate and ultrasonic extraction methods.

\section{References Cited}

Wolf, Ruth E., Morrison, Jean M., and Goldhaber, Martin B., 2007, Simultaneous determination of $\mathrm{Cr}(\mathrm{III})$ and $\mathrm{Cr}(\mathrm{VI})$ using reversed-phased ion-pairing liquid chromatography with dynamic reaction cell inductively coupled plasma mass spectrometry: Journal of Analytical Atomic Spectrometry, vol. 22, p. 1051-1060. 


\section{Evaluation of Extraction Methods for Hexavalent Chromium Determination in Dusts, Ashes, and Soils}

Ruth E. Wolf and Stephen A. Wilson

U.S. Geological Survey, MS 964D, Denver Federal Center, Denver, CO 80225

\section{ZUSGS}

Note: The following terms are used interchangeably in this presentation for hexavalent chromium: $\mathrm{Cr}(\mathrm{VI})$ and $\mathrm{Cr}^{+6}$. Trivalent chromium is referred to as $\mathrm{Cr}(\mathrm{III})$ or $\mathrm{Cr}^{+3}$. 


\section{Introduction}

- Several projects at USGS involve the determination of hexavalent chromium, $\mathrm{Cr}(\mathrm{VI})$, in a wide variety of matrices including soils, wild fire ash, and air monitoring filters

- One of the difficulties in speciation analyses of solid samples is finding a suitable extraction method for the a suitable extraction
species of interest

- The extraction method must be compatible with the analytes of interest and be compatible with the analytical determination method(s)

- The extraction method must also be able to accommodate a limited amount of sample and not generate an excessive amount of waste

\section{₹USGS}
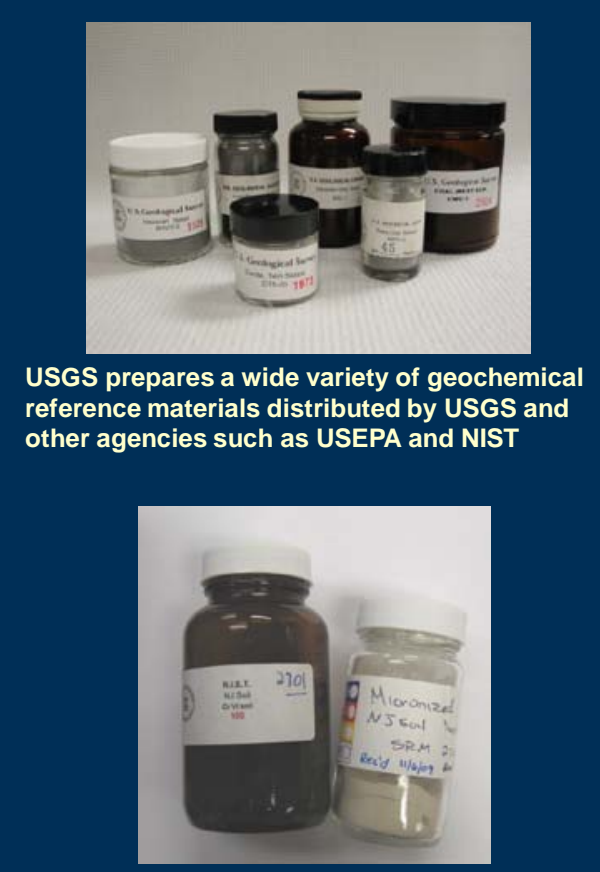

$\mathrm{Cr}(\mathrm{VI})$ reference materials in preparation by USGS (NIST 2701 and 2700)

Several projects at USGS require the determination of hexavalent chromium, $\operatorname{Cr}(\mathrm{VI})$, in a wide variety of matrices, including waters, leachates, soils, ashes, and air filters. One of the difficulties in the speciation analysis of solid materials is finding a suitable extraction method for the species of interest. The extraction method must be compatible with the analytical determination methods used and ideally require a small amount of sample and not generate a large quantity of waste. The photographs show some of the geochemical reference materials prepared by the USGS, including the hexavalent chromium in soil materials sold by NIST as SRM 2701 and SRM 2700. 


\section{USGS Reference Materials Project}

- Work with agencies to develop necessary natural matrix reference materials

- For method validation and quality control

- Can also provide contract services to commercial entities

- More Info:

- http:I/minerals.cr.usgs.go v/geo_chem_stand/

\section{ZUSGS}

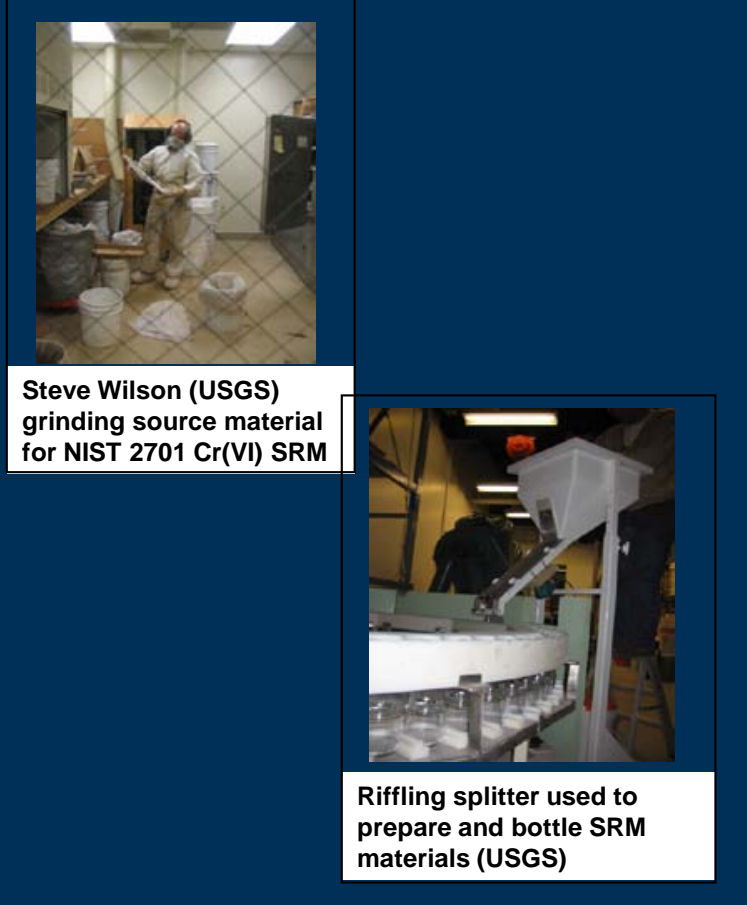

The USGS Reference Materials Project has been in place at USGS since the early 1950s. The purpose of this project is to develop natural matrix reference materials for geochemical analysis. These materials are used for method validation and quality control in a large number of laboratories around the world. USGS also prepares reference materials for other agencies such as NIST, NASA, USEPA, BOR, etc. In the case of NIST, many of the soil reference materials (for example, SRM 2709, 2710, 2711, etc.) are prepared by USGS. In some cases we can also provide contract services to prepare reference materials for commercial entities where no other source exists. More information can be found on our Web site: http://minerals.cr.usgs.gov/geo_chem_stand/ 


\section{Available $\mathrm{Cr}(\mathrm{VI})$ Extraction Methods - Solids}

- USEPA Method 3060A - Alkaline Digestion for Hexavalent Chromium

- $0.28 \mathrm{M} \mathrm{Na}_{2} \mathrm{CO}_{3} / 0.5 \mathrm{M} \mathrm{NaOH}$ with phosphate buffer and $\mathrm{MgCl}_{2}$ precipitation agent, $\mathrm{pH}>11.5$, hotplate

- Applicable to soils and solid wastes

- Requires $2.5 \mathrm{~g}$ sample and generates $100 \mathrm{~mL}$ of extract

- Analysis by UV-Vis (USEPA 7196)

- Ion Chromatography (USEPA 7199)

- De-ionized water, buffered and un-buffered extraction

- Applicable to soils, ashes, other solid materials

- Analysis by UV-Vis after 1, 5-diphenyl carbazide (DPC) derivitization, Ion Chromatography, or IC/HPLC ICP-MS

\section{₹USGS}

Recently, USGS prepared a soil reference material for NIST in conjunction with the New Jersey Department of Environmental Quality. During the development of this reference material, we reviewed the methods available for the determination of hexavalent chromium in solid materials. Most of you are familiar with USEPA Method 3060A from the SW-846 Manual. This is a strong alkaline digestion. It requires a large quantity of sample, $2.5 \mathrm{~g}$, and generates a significant amount of waste, $100 \mathrm{~mL}$. Other extraction methods that we have used in our laboratories include de-ionized water leaches, using either buffered or unbuffered water. This method can be used with a variety of different detection methods. 


\section{Available $\mathrm{Cr}(\mathrm{VI})$ Extraction Methods - Filters}

- OSHA ID-215 - Hexavalent Chromium in Air Filters

- $10 \% \mathrm{Na}_{2} \mathrm{CO}_{3} / 2 \% \mathrm{NaHCO}_{3}$ with phosphate buffer and Mg sulfate precipitation agent, $\mathrm{pH} 8$, hotplate

- Applicable to quartz or PVC air filters

- Analysis by lon Chromatography and UV-detection after DPC derivitization

- NIOSH 7605 - Hexavalent Chromium in Air Filters

- $3 \% \mathrm{Na}_{2} \mathrm{CO}_{3} / 2 \% \mathrm{NaOH}$, hotplate

- Applicable to $37 \mathrm{~mm}$ PVC air filters $(5.0 \mu \mathrm{m})$

- Analysis by lon Chromatography with post column derivitization (DPC) and UV-detection at $540 \mathrm{~nm}$

- NIOSH 7703 - Hexavalent Chromium by Field-Portable Spectrophotometry

- $0.05 \mathrm{M}\left(\mathrm{NH}_{4}\right)_{2} \mathrm{SO}_{4} / 0.05 \mathrm{M} \mathrm{NH}_{4} \mathrm{OH}$, pH 8, ultrasonic

- Applicable to $37 \mathrm{~mm}$ PVC air filters (5.0- $\mu \mathrm{m})$

- Analysis by UV-Vis, DPC complex, 540nm

\section{ZUSGS}

There are also published methods available from OSHA and NIOSH for the determination of hexavalent chromium in air filters. The three methods here are examples of some of the more widely used methods. All are buffered alkaline extractions. We began looking at these methods for some work we were performing for the USEPA National Enforcement Investigations Center (NEIC). 


\section{Analytical Method ${ }^{1}$}

- HPLC - reversed phase, ion-pairing

- Column: Brownlee C8

- $3.3 \mathrm{~cm} \times 3 \mu \mathrm{m}$, Si-based ${ }^{2}$

- Column Oven $35^{\circ} \mathrm{C}$

- Mobile Phase:

- $2 \mathrm{mM}$ tetrabutylammonium hydroxide (TBAOH) $+0.5 \mathrm{mM} \mathrm{K}$ EDTA, $\mathrm{pH}=7.4-7.6$

- EDTA converts $\mathrm{Cr}$ (III) to an anionic EDTA-Cr(III) complex so it can be separated under same conditions as $\mathrm{Cr}(\mathrm{VI})$ species

- $5 \% \mathrm{MeOH}$ added online

- Autosampler $10^{\circ} \mathrm{C}$

- Required for sample stability

- Samples: Diluted minimally 1:1 in mobilephase held at $10^{\circ} \mathrm{C}, 50 \mu \mathrm{L}$ injection

- DRC-ICP-MS

- Reaction gas: $\mathrm{N}_{2}$ or $\mathrm{NH}_{3}$

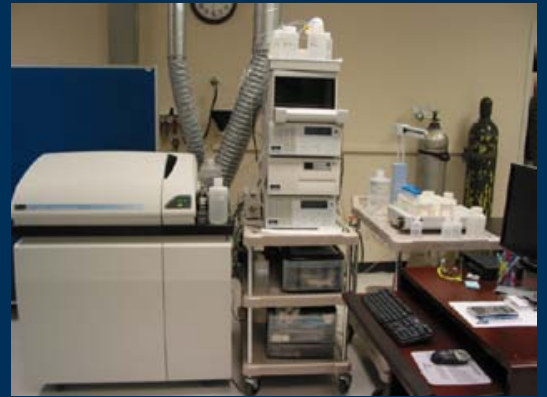

The use of company, trade, and/or product names is for identification purposes only and does not imply endorsement by the United States Government.

- removes ${ }^{40} \mathrm{Ar}^{12} \mathrm{C}$ interference on ${ }^{52} \mathrm{Cr}$

- Sample Introduction: Baffled quartz cyclonic spray chamber and Meinhard TQ-30-A3 nebulizer

¿USGS

${ }^{1}$ Complete description in J. Anal. At. Spectrom., 2007, v.22, p.1051-1060 Stated column working range to $\mathrm{pH}=7$; however, have run up to $\mathrm{pH}=8$ without significant column life issues

Since any extraction method must be compatible with the analytical determination step, here is a brief overview of the method we have been using in our laboratory for chromium speciation. The details have been published in JAAS in 2007 (J. Anal. At. Spectrom., 2007, v.22, p.1051-1060). Briefly we use a reversed-phase ion-pairing HPLC separation followed by determination by ICP-MS. The mobile phase is $2 \mathrm{mM}$ TBAOH with EDTA added to complex the $\mathrm{Cr}$ (III) present, converting it to an anionic $\mathrm{Cr}(\mathrm{III})$-EDTA complex. The ICP-MS is equipped with a Dynamic Reaction Cell to remove interferences on ${ }^{52} \mathrm{Cr}$ and we use either nitrogen or ammonia as the DRC reaction gas. 


\section{Method Performance and Considerations}

- Verified individual $\mathrm{Cr}(\mathrm{III})$ and $\mathrm{Cr}(\mathrm{VI})$ calibration stocks not contaminated

- Calibrated at 1, 2, 5, $10 \mathrm{ppb}$

- $\operatorname{Ran} 100,200,500$ ppt mixed standards

- Standards stable for $\mathbf{4 8}$ hours if kept at $\mathbf{1 0}$ ${ }^{\circ} \mathrm{C}$ at pH 7.4-7.5 or higher $<3 \%$

conversion of $\mathrm{Cr}(\mathrm{VI})$

- Determination of both $\mathrm{Cr}(\mathrm{III})$ and $\mathrm{Cr}(\mathrm{VI})$ in same run allows stability evaluations

- Amber glass HPLC vials showed 0.4-0.6 ppb Cr(VI) contamination

- Use clear glass or polypropylene vials

- Check for $\mathrm{Cr}(\mathrm{VI})$ stability, some plastic vials will promote conversion

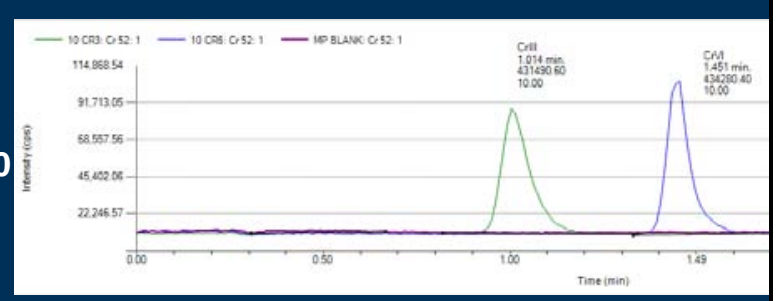

- $\quad$ Cr IDL = 100 ppt

- Cr PQL = 200 ppt ( $20 \%$ TV)

- Both $\mathrm{Cr}(\mathrm{III})$ and $\mathrm{Cr}(\mathrm{VI})$

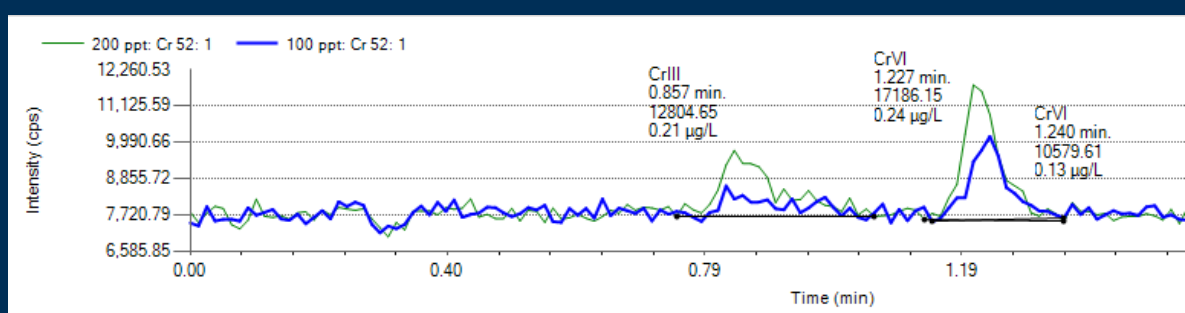

\section{₹USGS}

Calibration is performed using commercially available stock standards diluted in the mobile phase at 1, 2, 5, and 10 ppb. Detection limits and Practical Quantitation Limits (PQLs) were determined by the analysis of several low level spikes.

Using nitrogen as the reaction gas, the $\mathrm{PQL}$ for both $\mathrm{Cr}(\mathrm{III})$ and $\mathrm{Cr}(\mathrm{VI})$ is $200 \mathrm{ppt}$. This is the lowest level spike that was recovered within 20 percent of the true value. The IDL is 100 ppt. The ability of the method to $\mathrm{monitor} \mathrm{Cr}(\mathrm{III})$ and $\mathrm{Cr}(\mathrm{VI})$ in the same chromatographic run is useful for evaluating interconversion and species stability. 


\section{Analytical Figures of Merit:}

\begin{tabular}{|l|c|c|c|c|}
\hline \multirow{2}{*}{ Parameter } & \multicolumn{2}{|c|}{$\begin{array}{c}\mathrm{NH}_{3} \text { Reaction Gas } \\
\text { Flow 0.75, RPq=0.65 }\end{array}$} & \multicolumn{2}{c|}{$\begin{array}{c}\mathrm{N}_{2} \text { Reaction Gas } \\
\text { Flow 1.0, RPq=0.50 }\end{array}$} \\
\cline { 2 - 5 } & $\mathrm{Cr}(\mathrm{III})$ & $\mathrm{Cr}(\mathrm{VI})$ & $\mathrm{Cr}(\mathrm{III})$ & $\mathrm{Cr}(\mathrm{VI})$ \\
\hline Instrument Detection Limit (IDL), $\mu \mathrm{g} / \mathrm{L}$ & 0.09 & 0.06 & 0.1 & 0.1 \\
\hline Practical Quantitation Limit (PQL), $\mu \mathrm{gg} / \mathrm{L}$ & 0.2 & 0.2 & 0.2 & 0.2 \\
\hline
\end{tabular}

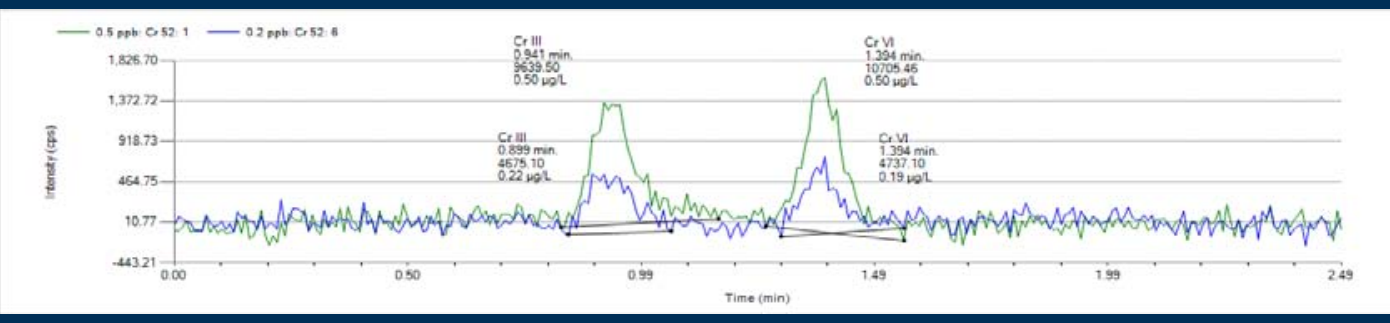

Chromatogram showing low calibration standard at $0.5 \mu \mathrm{g} / \mathrm{L}$ and standard at PQL of $0.2 \mu \mathrm{g} / \mathrm{L}$

\section{ఇUSGS}

Using ammonia as the reaction gas, slightly better detection limits can be obtained. However, the PQL is the same for both reaction gases tested at $200 \mathrm{ppt}$. The chromatogram shows low-level chromium standard at 200 and $500 \mathrm{ppt}$, recovered within 20 percent of the expected value. 


\section{Performance of $\mathrm{Cr}(\mathrm{VI})$ Extraction Methods with HPLC-ICP-MS Detection:}

- Preliminary investigations using various buffer solutions reported in established regulatory methods and by Ashley and others ${ }^{1}$ were carried out using spikes of $\mathrm{Cr}(\mathrm{III})$ and $\mathrm{Cr}(\mathrm{VI})$ in blank extraction solutions and comparing chromatograms to spikes in the HPLC mobile phase:

\begin{tabular}{|l|c|c|c|}
\hline Buffer Solution Tested & \multicolumn{1}{|c|}{ Stock Concentrations } & Tested Concentration & $\mathrm{pH}$ \\
\hline Phosphate - pH 8 & $1 \mathrm{M} \mathrm{K}_{2} \mathrm{HPO}_{4}-0.06 \mathrm{M} \mathrm{K}_{2} \mathrm{PO}_{4}$ & $10 \mathrm{mM}, 20 \mathrm{mM}$ & 8.4 \\
\hline Carbonate - pH 9 & $0.1 \mathrm{M} \mathrm{Na}_{2} \mathrm{CO}_{3}-0.9 \mathrm{M} \mathrm{NaHCO}_{3}$ & $10 \mathrm{mM}, 20 \mathrm{mM}$ & 9.2 \\
\hline Sulfate - pH 10 & $1 \mathrm{M}\left(\mathrm{NH}_{4}\right)_{2} \mathrm{SO}_{4}-1 \mathrm{M} \mathrm{NH}_{4} \mathrm{OH}$ & $20 \mathrm{mM}, 50 \mathrm{mM}$ & 10.3 \\
\hline
\end{tabular}

${ }^{1}$ Ashley and others, J. Environmental Monitor., 2003, v.5, p.707-716)

\section{¿USGS}

Some of our initial work was to determine a suitable extraction method for the determination of hexavalent chromium on quartz fiber air filters. Based on the OSHA and NIOSH methods, several buffer systems were tested with our analytical method to determine their compatibility. We tested phosphate, carbonate, and sulfate buffers for extraction by spiking in each species into the buffer solution and then analyzing them using our HPLC-DRC-ICP-MS method. 


\section{Results of Extraction Tests:}

- Phosphate and ammonium sulfate buffer solutions were incompatible with HPLC separation method

- Caused multiple or broad peaks to occur

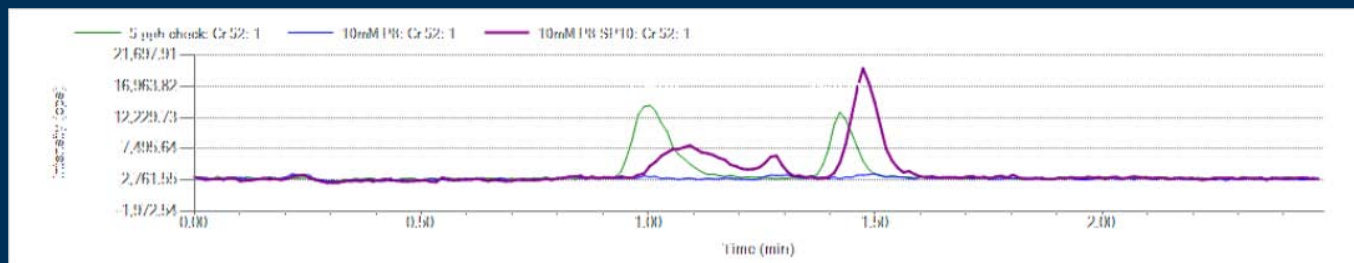

$5 \mathrm{ppb} \mathrm{Cr}(\mathrm{III})$ and $\mathrm{Cr}(\mathrm{VI})$ in Mobile Phase (green line) and in $20 \mathrm{mM} \mathrm{K} \mathrm{KPO}_{4} / \mathrm{KH}_{2} \mathrm{PO}_{4}$ buffer at pH 8 (purple line)

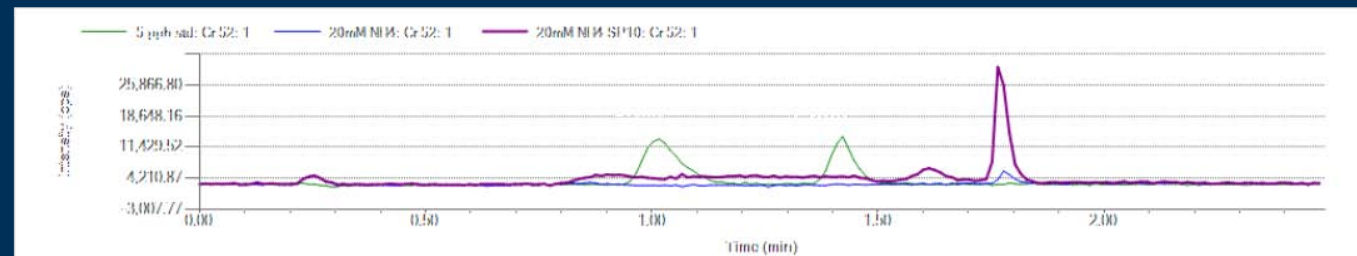

$5 \mathrm{ppb} \mathrm{Cr}(\mathrm{III})$ and $\mathrm{Cr}(\mathrm{Vl})$ in Mobile Phase (green line) and in $20 \mathrm{mM}\left(\mathrm{NH}_{4}\right)_{2} \mathrm{SO}_{4} / \mathrm{NH}_{4} \mathrm{OH}$ buffer at pH 10 (purple line)

\section{‡USGS}

The two chromatograms above show $5 \mathrm{ppb} \mathrm{Cr}(\mathrm{III})$ and $\mathrm{Cr}(\mathrm{VI})$ standards in the mobile phase (green line) and the same spikes in the phosphate and ammonium sulfate extract solutions (purple line). Both of these buffer systems caused multiple or broad peaks to occur and were deemed incompatible with the analytical method. 


\section{Results of Extraction Tests (con't):}

- Selected bicarbonate buffer system for further testing

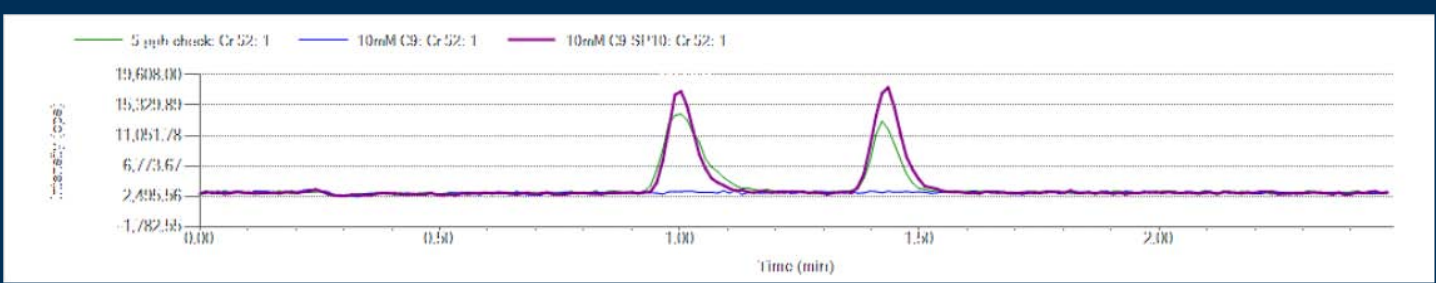

$5 \mathrm{ppb} \mathrm{Cr}(\mathrm{III})$ and $\mathrm{Cr}(\mathrm{VI})$ in Mobile Phase (green line) and in $10 \mathrm{mM} \mathrm{Na}_{2} \mathrm{CO}_{3} / \mathrm{NaHCO}_{3}$ buffer at pH 9 (purple line)

\section{‡USGS}

However, the $5 \mathrm{ppb} \mathrm{Cr}(\mathrm{III})$ and $\mathrm{Cr}(\mathrm{VI})$ spikes in the $10 \mathrm{mM}$ sodium carbonate/bicarbonate buffer system at $\mathrm{pH} \sim 9.3$ (purple line) are at the same retention time as the standards in the mobile phase (green line) and peak shapes and separation are good. This is the system we will perform further testing on. 


\section{Test Extraction Method Evaluated}

- $1 \mathrm{mM} \mathrm{Na}_{2} \mathrm{CO}_{3} / 9 \mathrm{mM} \mathrm{NaHCO}, \mathrm{pH} 9.0$ extraction fluid

- Sample placed in $\mathbf{5 0} \mathrm{mL}$ centrifuge tube (PP)

- 1" strip - large air filters or whole $45 \mathrm{~mm}$ filters, folded in half

- $50 \mathrm{~mL}$ extraction solution added, tube capped

- Sonicated for $\mathbf{3}$ hours without heat

- Time arbitrarily selected, testing to evaluate minimum time required

- After 3 hours, temperature in ultrasonic bath was $\sim 60^{\circ} \mathrm{C}$

- Solutions allowed to come to room temperature $\sim 1$ hour

- Solution filtered with $\mathbf{0 . 4 5} \boldsymbol{\mu m}$ syringe filter

- Acrodisc (PDVF) using $10 \mathrm{~mL}$ disposable syringes into $15 \mathrm{~mL}$ tubes

- Filtered solutions at $4^{\circ} \mathrm{C}$ until analysis, analyzed within 3-4 hours

- All sample solutions were diluted (minimum 1:1) with mobile phase prior to analysis for $\mathrm{pH}$ adjustment and matrix matching

- All samples run with analytical spikes to evaluate possible signal enhancement effects from sample matrix (high $\mathrm{Na}^{+}$levels)

\section{₹USGS}

For extraction of air filters, we tested the $10 \mathrm{mM}$ sodium carbonate/sodium bicarbonate buffer system. Filter samples were placed in $50 \mathrm{~mL}$ polypropylene centrifuge tubes and sonicated for 3 hours (without heat). At the end of the sonication step, the temperature in the ultrasonic bath was approximately $60^{\circ} \mathrm{C}$. The solutions were then filtered using $0.45 \mu \mathrm{m}$ syringe filters and disposable syringes. The extracts were diluted a minimum of 1:1 with the HPLC mobile phase and analyzed as soon as possible. Analytical spikes were performed on all samples. 


\section{Method Validation - Air Filters}

- 45 mm quartz filters treated with $1 \mathrm{~N} \mathrm{NaOH}$

- Blank 8x10 filters used for air sample collection

- NIST 2701 - Cr(VI) in soil loaded on quartz filter

- BCR-545 (IRMM, Belgium) - CRM for Cr(VI) in welding dust loaded on filter

\begin{tabular}{|c|c|c|c|}
\hline Sample & $\mathrm{Cr}(\mathrm{VI})$ amount & \% Recovery & \%RSD \\
\hline Blank 45mm Qtz filter (NaOH) & Not detected & & \\
\hline NaOH Qtz 45mm, n=3 & $50 \mu \mathrm{g} \mathrm{K}_{2} \mathrm{CrO}_{7}-\mathrm{sol}$ & 107 & 5.2 \\
\hline NaOH Qtz 45mm, n=3 & $50 \mu \mathrm{g} \mathrm{PbCrO}_{7}-$ insol & 108 & 4.9 \\
\hline NaOH Qtz 45mm, n=2 & $50 \mu \mathrm{K}_{2} \mathrm{CrO}_{7}+\mathrm{PbCrO}_{7}$ & 108 & 1.8 \\
\hline Blank (8x10) filter $(\mathrm{NaOH}) \mathrm{n}=4$ & 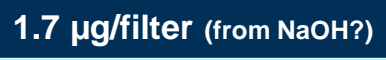 & -- & 38 \\
\hline 8x10 Filter (NaOH) spiked, n=4 & $50 \mu \mathrm{g} \mathrm{K}_{2} \mathrm{CrO}_{7}-\mathrm{sol}$ & 120 & 15 \\
\hline NIST $2701, n=2,6$ runs & $551.2 \mu \mathrm{g} / \mathrm{g}$ & 88 & 9.0 \\
\hline BCR-545, n=3, 50x & $40,200$ ( 600$) \mu g / g$ & 99 & 1.2 \\
\hline BCR-545, n=3, 250x & $40,200(600) \mu g / g$ & 102 & 4.1 \\
\hline
\end{tabular}

\#USGS

Untreated 8"x10" quartz filters analyzed previously did not show $\mathrm{Cr}(\mathrm{VI})$ present

These are the method validation results for the air filter extraction method. Potassium dichromate and lead chromate were spiked onto blank filters to assess recovery for soluble $\mathrm{Cr}(\mathrm{VI})$ and insoluble $\mathrm{Cr}(\mathrm{VI})$, respectively. Recoveries for both were excellent. BCR-545 reference material for $\mathrm{Cr}(\mathrm{VI})$ in welding dust was also analyzed in triplicate with an average of 100 percent recovery using this ultrasonic extraction method. NIST $2701-$ Hexavalent Chromium in Soil, was also brushed onto a filter and extracted with reasonable results, 88 percent recovery. 


\section{Soil Extraction Study:}

- USEPA Method 3060A Digestion as written is incompatible with HPLC-ICP-MS detection method

- Phosphate buffer disrupts ion-pairing chromatography

- Requires $50 x$ to $100 x$ dilution prior to analysis

- $2.5 \mathrm{~g}$ sample requirement and strong basic ( $\mathrm{pH} \sim 13)$ extraction solution results in over $100 \mathrm{~mL}$ of digestate for disposal

- Note: less than $1 \mathrm{~mL}$ required for analysis!

- $\mathrm{Mg}$ precipitation agent forms a gelatinous $\mathrm{Mg}(\mathrm{OH})_{2}$ or $\mathrm{Mg}\left(\mathrm{CO}_{3}\right)_{2}$ precipitate that is difficult to filter and wash, requires disposal

- Similar to coprecipitation method used to prepare microanalytical carbonate standards for LA-ICP-MS

- Could result in analyte loss (need to verify by SEM)

- Desirable to find an extraction method for soils that is compatible with the detection method of choice and easier to use and results in less waste

\section{₹USGS}

USEPA Method 3060A as written is incompatible with our HPLC-ICP-MS detection method without large dilutions prior to analysis. The phosphate buffer added to the extraction solution appears to disrupt the ion-pairing separation. This requires extracts to be diluted 1:50 or 1:100 which increases detection limits. In addition the magnesium coprecipitation agent results in a flocculent precipitate which is hard to wash and filter. We have also observed poor recoveries when the magnesium is added, possibly due to co-precipitation of some of the hexavalent chromium with the magnesium hydroxide/carbonate precipitate. We will verify this with SEM. This is similar to a coprecipitation method we use at USGS for preparing magnesium and calcium carbonate microanalytical standards. In addition the method results in a large amount of waste and is operationally difficult to perform because of the numerous transfer and filtration steps required. 


\section{Evaluation of $\mathrm{Cr}(\mathrm{VI})$ soil extractions}

- USEPA Method 3060A as written

- Modified USEPA Method 3060A

- Omit phosphate buffer and $\mathrm{Mg}$, reduce sample size to $\mathbf{0 . 2} \mathrm{g}$ and final volume to $50 \mathrm{~mL}$

- Hotplate method with $1 \mathrm{mM} \mathrm{Na} \mathrm{CO}_{3} / 9 \mathrm{mM} \mathrm{NaHCO}, \mathrm{pH} \sim 9.0$ extraction fluid, $0.5 \mathrm{~g}$ sample, $50 \mathrm{~mL}$ extraction fluid

- Ultrasonic method with $1 \mathrm{mM} \mathrm{Na}_{2} \mathrm{CO}_{3} / 9 \mathrm{mM} \mathrm{NaHCO}$, $\mathrm{pH} 9.0$ extraction fluid (successful for air filters)

- Evaluate bulk ultrasonic method with $0.5 \mathrm{~g}$ sample placed in bottom of centrifuge tube, $50 \mathrm{~mL}$ extraction fluid, $2 \mathrm{hr}$

- Evaluate filter suspended ultrasonic method with $0.05-0.15 \mathrm{~g}$ sample placed on a quartz filter prior to extraction, $1 \mathrm{hr}$

- Evaluate effect of particle size on extraction efficiency

- Extract SRM materials as provided (mean particle size $\sim 200 \mu \mathrm{m})$

- Micronize SRM materials to mean particle size $\sim 30 \mu m$

- Evaluate stability of micronized materials over time

\section{ZUSGS}

So, we looked at evaluating a variety of extractions for $\mathrm{Cr}(\mathrm{VI})$ in the recently developed NIST 2701 soil reference material and in the new NIST 2700 reference material. We evaluated USEPA Method 3060A as written, a modified version of USEPA Method 3060A where the sample size and extraction solution volume was reduced and the phosphate buffer and magnesium coprecipitation regent omitted. We also evaluated the $10 \mathrm{mM}$ sodium carbonate $\mathrm{pH} 9$ extract successfully used for $\mathrm{Cr}(\mathrm{VI})$ in air filters both in a hot plate digestion and using ultrasonic extraction. We also looked at the effect of particle size on the extraction efficiency by comparing NIST 2701 as shipped (approximately $200 \mu \mathrm{m}$ particles) with a portion that had been reduced to smaller particle sizes of approximately $30 \mu \mathrm{m}$. 


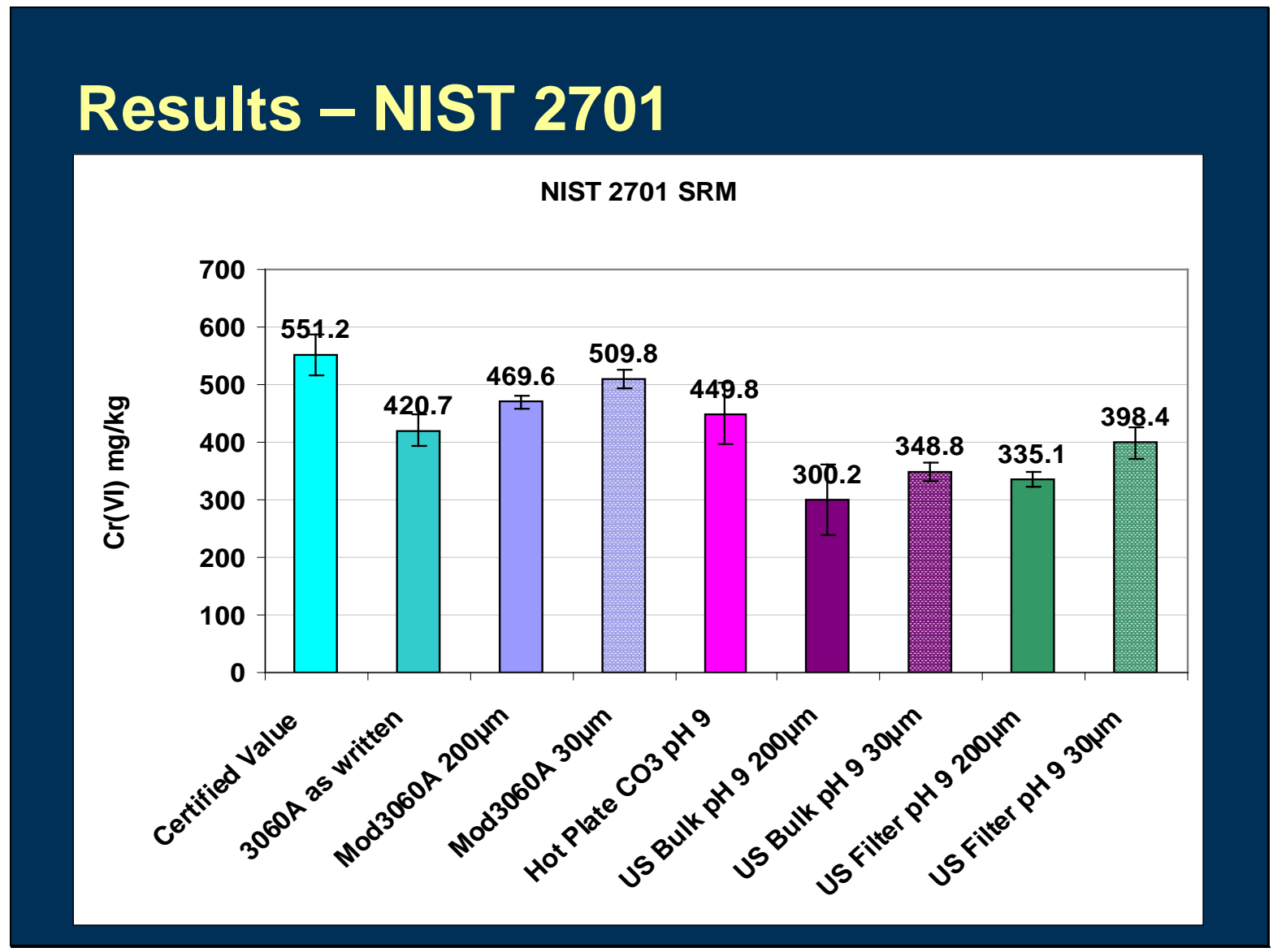

So, here are the results. The certified value of NIST 2701 is $551 \mathrm{mg} / \mathrm{kg}$. The error bars in all cases are 1 times the standard deviation of replicate samples (usually $\mathrm{n}=3$ ). For USEPA Method 3060A we obtained about 75 percent recovery, which is consistent with Stu Nagourney's findings presented in his earlier talk. Using the modified version of USEPA Method 3060A we obtained improved recoveries to about 85 percent recovery. Using the modified USEPA Method 3060A on a micronized portion of NIST 2701 where the particle size had been reduced to approximately 30 $\mu \mathrm{m}$, we obtain even better (92 percent) recoveries. Using the hotplate sodium carbonate we obtain recoveries similar to those from the modified USEPA Method 3060A - about 82 percent for NIST 2701 as shipped (approximately $200 \mu \mathrm{m}$ particles). The ultrasonic bulk methods resulted in low recoveries (54 percent) which were improved somewhat by micronizing the sample before extraction (63 percent). Suspending the sample on a quartz filter prior to ultrasonic extraction also improved extraction efficiencies to 61 percent and 72 percent for the as shipped and micronized samples, respectively. Further testing will be done with the ultrasonic methods at elevated temperatures to see if efficiencies can be improved as this was an operationally simple method to perform and our earlier experiments with the air filters resulted in more favorable recoveries. 


\section{Results - NIST 2700}

\section{1:40 dilution NIST 2701 with quartz sand}

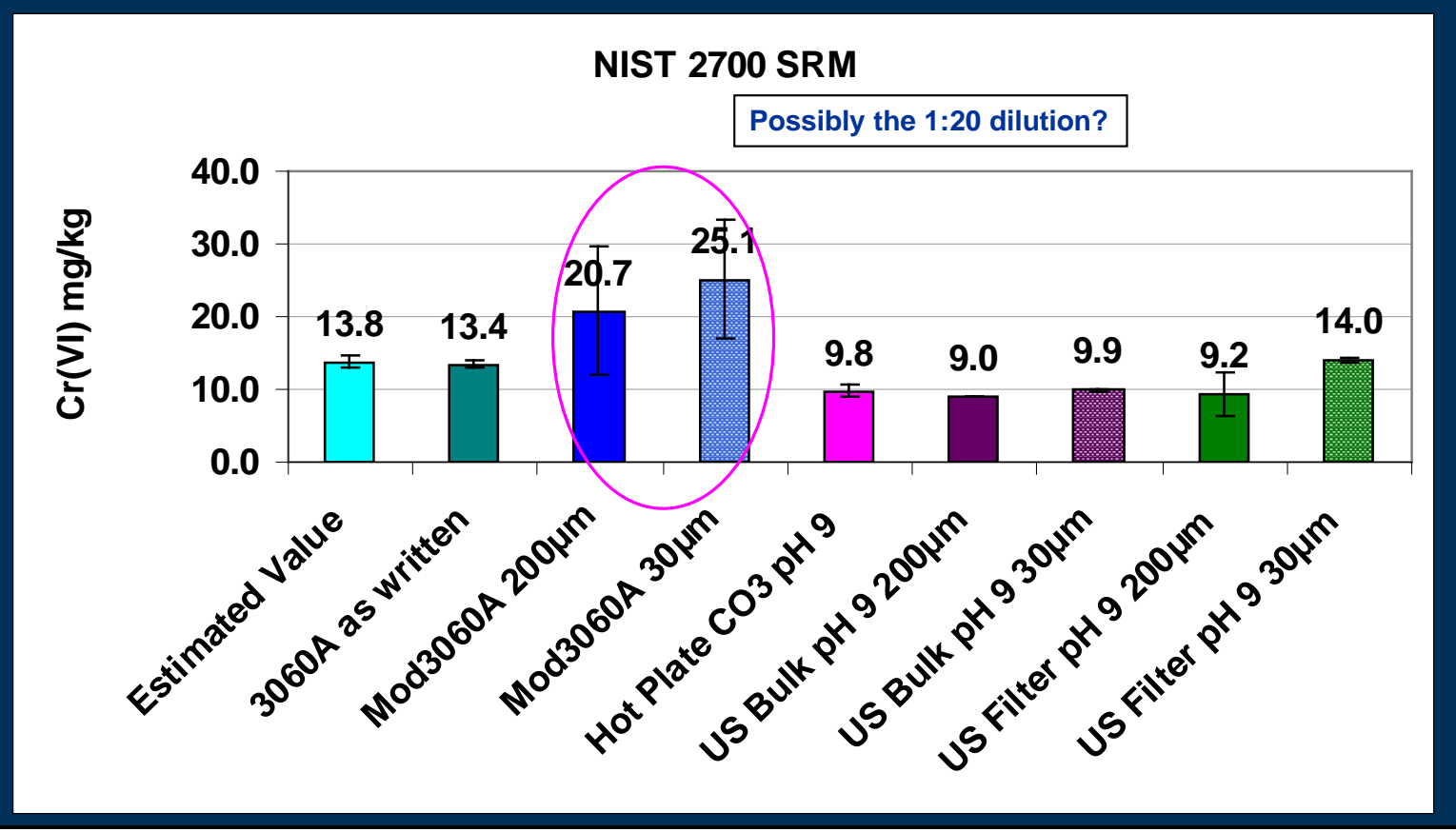

For NIST 2700, which is some of the original material from NIST 2701 diluted 1:40 with ground high-purity quartz we get close to the predicted value of $13.8 \mathrm{mg} / \mathrm{kg}$ using USEPA Method 3060A as written. It is thought that the dilution of the matrix is responsible for the improved extraction efficiency. The modified USEPA Method 3060A results are higher than expected but it is possible this sample was actually a 1:20 dilution (which would give an expected value of $27.5 \mathrm{mg} / \mathrm{kg}$ $\mathrm{Cr}(\mathrm{VI}))$. This set of samples will need to be re-analyzed to verify the data. The 10-mM sodium carbonate buffer extraction led to $71-101$ percent recoveries. More testing needs to be done to further validate the results for these samples. 


\section{Conclusions:}

- Ultrasonic extraction method with pH 9 sodium carbonate buffer achieved 100\% recoveries on Cr(VI) SRM BCR-545 and test spikes

- Modified USEPA Method 3060A extraction achieved best recoveries for NIST 2701

- Hotplate pH 9 sodium carbonate extraction efficiencies equivalent to modified USEPA 3060A for NIST 2701

- For all methods better recoveries were obtained for micronized sample with smaller particle size

- Recoveries for micronized sample stored 18 months within $10 \%$ of freshly prepared sample

- Ultrasonic extraction method efficiency was improved by suspending the sample on a quartz filter prior to extraction

- Efficiencies for soils not as good as previously achieved for dusts suspended on filters and BCR-545

\section{ZUSGS}

In conclusion, the ultrasonic extraction method using a pH 9 sodium carbonate buffer solution achieved 100 percent recoveries for SRM BCR-545 - Hexavalent chromium in an air filter. For the NIST 2701 soil, the modified version of USEPA Method 3060A achieved the best recoveries. The hotplate $\mathrm{pH} 9$ sodium carbonate extraction provided similar recoveries for NIST 2701 as did the modified USEPA Method 3060A extraction. For all samples better recoveries were obtained by micronizing the sample to reduce the particle size prior to extraction. More work needs to be done using the ultrasonic extraction method to see if this is a viable alternative since this was an operationally easy method to perform and it worked well for the air filter samples. 


\section{Next Steps:}

- Repeat Modified USEPA Method 3060A method on both 2701 and 2700 to verify results and improve statistics

- Repeat Hotplate pH 9 sodium carbonate extraction on 2701 and 2700

- Evaluation ultrasonic extraction method at different extraction times and temperatures

- Evaluate effects of possible oxidation/reduction reactions during extraction

- Contact: Ruth E. Wolf (303) 236-2470, rwolf@usgs.gov

\section{₹USGS}

We will continue this work by repeating the Modified US EPA Method 3060A extraction on both NIST 2701 and 2700 to verify the results. We also intend to continue work on the hotplate and ultrasonic extraction methods using the $10 \mathrm{mM}$ sodium carbonate buffer system as different extraction times and temperature. Additionally we will evaluate the potential for oxidation/reduction reactions during the modified USEPA Method 3060A extraction and the sodium carbonate extraction which could change the sample speciation during extraction. 